\title{
Comparative Study of Water and Oil Extracts of Moringa (Moringa oleifera) Leaves on Immune Response and Hepatic Oxidative Status in Rats
}

Fatma, A.Khalil, Hanaa M. Abd-El Fattah, Heba A. A. Barakat and Alyae, M.S. Gabal

Biochemistry and Nutrition Department, Women's College, Ain Shams University, Cairo, Egypt.

\section{Abstract:}

This study was conducted to investigate the biochemical effects of Paracetamol which chemically named as $\mathrm{N}$-acetyl-p-aminophenol (APAP) high dose on experimental animals and to study the antiinflammatory, immunomodulatory, antioxidant and hepatoprotective activity of oil (ethanolic) and aqueous (water) extracts of Moringa oleifera ( $M$. oleifera) leaves supplementation as well as choosing the best extract. This study was carried out on eighty three male adult albino rats of Sprague-Dawely strains which were divided into eight groups, of ten animals each except APAP control group were composed of thirteen rats, all rats were fed commercial diet. Group (I): rats received a placebo $1 \mathrm{~g}$ of $0.9 \%$ normal saline by oral intubation daily, while other groups received a high dose of APAP (1g APAP/kg body weight) daily by oral intubation to induce hepatotoxicity. Group (II): rats received APAP dose daily without any treatments. Groups (III, IV and V): rats received APAP dose and supplemented with water extract of M.olifera at three tested doses (200,300 and $400 \mathrm{mg} / \mathrm{Kg}$ body weight) respectively daily by oral intubation. While groups (VI, VII and VIII), rats received APAP dose and supplemented with ethanolic extracts of M.olifera at three tested doses (200,300 and 400mg/Kg body weight) respectively daily for four weeks.

At the end of the experimental period (four weeks) rats were anesthetized using diethyl ether anesthesia after overnight fasting. Blood samples were collected from the hepatic portal vein and serum was separated for analysis. Then rats sacrificed and abdomen was opened at greater curvature as liver and spleen were removed for biochemical and microscopical examination.

The present study showed that APAP administration caused a significant increase in the level of hepatic protein carbonyl group (PCG), malondialdehyde (MDA) and nitric oxide (NO) levels. On the other hand, reduced blood glutathione (GSH) level, serum catalase (CAT), glutathione-S-transferase (GST), and glutathione reductase (GR) activities as well as serum immunoglobulins (IgG and IgM) levels were significantly decreased compared to healthy control group at $(p \leq 0.05)$. The inflammatory markers like serum tumor necrosis factor alpha (TNF- $\alpha$ ), interleukin 1 beta (IL1b) levels and myeloperoxidase (MPO) activity 
increased in APAP control group. The study revealed the toxic effect of APAP on the liver function enzymes as? 国 serum? 国 galuedmyltransferase (? GT, aspartate aminotransferase (AST),

and alanine aminotransferase (ALT) activities were significantly increased in APAP control group compared to healthy control group at $(p \leq 0.05)$. Administration of water or ethanolic extracts at the tested doses $(200,300$ and $400 \mathrm{mg} / \mathrm{Kg}$ body weight of rats) daily resulted in a significant decrease in oxidative biomarkers, inflammatory markers, liver function enzymes activities and significant improvement in antioxidants levels and the immune function as compared with APAP hepatotoxicated rats at $(p \leq 0.05)$. Results of this study suggested that ethanolic extracts were more effective and the highest improvements were found in group which treated with the highest dose of the ethanolic extract $(400 \mathrm{mg} / \mathrm{kg}$ body weight).

Keywords: Moringa oleifera, paracetamol, oxidative stress, inflammation biomarkers, immunomodulatory activity.

\section{Introduction}

APAP is a readily available over-the-counter medication as an effective painkiller and fever suppressor. APAP retains a virtuous safety profile at therapeutic doses. However, when its therapeutic index is breached, it results in acute / chronic hepato-renal damage in both human and experimental animals (Karthivashan et al., 2015). The toxicity of APAP is closely related to its metabolism in both the liver and extra hepatic tissues. APAP is mainly metabolized by sulfation and glucuronidation. A small proportion is metabolized through cytochromes CYP2E1 and to a lesser extent CYP1A2 and CYP3A4, which produce a reactive metabolite, N-acetyl-p-benzoquione imine, (NAPQI). Liver APAP toxicity is associated with depletion of glutathione (GSH) followed by covalent binding of reactive APAP metabolites to tissue proteins resulting in a state of oxidative stress and inflammation (Singh et al., 2011a).

The search for drugs and dietary supplements derived from plants has accelerated. Medicinal properties of plants have also been investigated in the light of recent scientific developments throughout the world, due to their potent pharmacological activities, low toxicity and economic viability, when compared with synthetic drugs (Pracheta et al., 2011). Therefore, owing to its vast medicinal potentials, $M$. oleifera plant has recently gained much attention. Although native to South Asia (particularly India), M. oleifera plant is now widely cultivated across Nigeria and almost the entire West African sub-region. M. oleifera is the best known of the thirteen species in the genus Moringa of family Moringaceae (Mahmood 
et al., 2010). M. oleifera is coming to the forefront as a result of scientific evidence that $M$. oleifera is an important source of naturally occurring phytochemicals and this provides a basis for future viable developments (Paliwal et al., 2011). M. oleifera leaves have been characterized to contain a desirable nutritional balance, containing vitamins, minerals, amino acids, and fatty acids (Razis et al., 2014). Additionally, the leaves are reported to contain various types of antioxidant compounds such as ascorbic acid, flavonoids, phenolics, and carotenoids (Vongsak et al., 2014). M. oleifera provides a rich and rare combination of zeatin, quercetin, beta-sitosterol and kaempferol. In addition to its high nutritional value, $M$. oleifera Lam is very important for its medicinal value. Various parts of this plant such as leaves, roots, seed, bark, fruit, flowers and immature pods act as cardiac and circulatory stimulants, possess antitumor, antipyretic, anti-inflammatory, antiulcer, antispasmodic, diuretic, antihypertensive, cholesterol lowering, antioxidant, antidiabetic, hepatoprotective, antibacterial and antifungal activities and are being employed for the treatment of different ailments in the indigenous system of medicine (Neelima et al.,2016).

Aim of the work: This study was conducted to investigate the biochemical effects of APAP overdose on experimental animals and to study the anti-inflammatory, immunomodulatory, antioxidant and hepatoprotective activity of ethanolic and water extracts of $M$. oleifera leaves supplementation as well as choosing the best extract.

\section{Materials and Methods}

\subsection{Materials}

2.1.1. Chemical:-Paracetamol also known as acetaminophen (APAP) was obtained from ELGomhouria Company for Trading Chemicals, Cairo, Egypt. 1g of APAP was suspended in $1 \mathrm{ml}$ distilled water and given to rats.

2.1.2. Animals: - Eighty three adult male albino rats of Sprague-Dawely strains weighing $(150 \pm 5 \mathrm{~g})$, were supplied by Research Center of the Faculty of Medicine, Ain Shams University, Cairo, Egypt.

2.1.3. Diet: - Standard commercial diet according to NRC, (1995) which obtained from Egyptian Organization for Biological Products and Vaccines (Helwan, Egypt).

2.1.4. Plant: - M. oleifera leaves were purchased fresh from Moringa production unit in the National Research Center, Giza, Egypt. Leaves were washed with distilled water and dried in vacuum oven at $50{ }^{\circ} \mathrm{C}$ for $10 \mathrm{~h}$. and then crushed. 


\subsection{Methods}

\subsubsection{Preparation of Moringa leaves extracts}

2.2.1.1. Preparation of water extract: - Dried powdered leaves was mixed with $10 \mathrm{ml}$ boiling distilled water for 5 minutes. The mixture then filtered twice through $2 \mu \mathrm{m}$ pore sterile filter paper into a sterile tube. The water extract stock solution $(100 \mathrm{mg} / \mathrm{ml})$ was freshly prepared and stored at $4^{\circ} \mathrm{C}$ for up to 5 days (Berkovich et al., 2013).

2.2.1.2. Preparation of ethanolic extract: - One gram dried powdered leaves was mixed with $10 \mathrm{ml}$ of $80 \%$ ethanol. The mixture was stirred using magnetic stirrer in air tight container for about 1 h., and then filtered. The filtrate was evaporated in rotary evaporator to remove ethanol (at $40-45^{\circ} \mathrm{C}$ and 250 r.p.m.). The ethanol free sample was weighed (100 mg) and suspended in $1 \mathrm{ml}$ distilled water to give final extract solution $(100 \mathrm{mg} / \mathrm{ml}$ ) (Babu et al., 2003).

2.3.Experimental Design: - Animals randomly classified into eight groups of ten animals each except APAP control group was composed of thirteen rats and treated as following: Group I: control group, rats fed commercial diet and received a placebo $1 \mathrm{~g}$ of $0.9 \%$ normal saline by oral intubation.; Group II: APAP control group, rats fed commercial diet and received $1 \mathrm{~g}$ APAP/kg body weight daily by oral intubation.; Group III : rats fed commercial pellets diet and received $1 \mathrm{~g} \mathrm{APAP} / \mathrm{kg}$ body weight with $200 \mathrm{mg}$ water extract of M.olifera leaves/Kg body weight daily.; Group IV: rats fed commercial pellets diet and received 1g APAP/kg body weight with $300 \mathrm{mg}$ water extract of M.olifera leaves/Kg body weight daily. Group V: rats fed commercial pellets diet and received $1 \mathrm{~g}$ APAP/kg body weight with $400 \mathrm{mg}$ water extract of M.olifera leaves/Kg body weight daily.; Group VI: rats fed commercial pellets diet and received $1 \mathrm{~g} \mathrm{APAP} / \mathrm{kg}$ body weight with $200 \mathrm{mg}$ ethanolic extract of M.olifera leaves/Kg body weight daily.; Group VII: rats fed commercial pellets diet and received $1 \mathrm{~g}$ APAP/kg body weight with $300 \mathrm{mg}$ ethanolic extract of M.olifera leaves/Kg body weight daily.; Group VIII: rats fed commercial pellets diet and received $1 \mathrm{~g}$ APAP/kg body weight with 400mg ethanolic extract of M.olifera leaves/Kg body weight daily. Animals were maintained on a natural light/dark cycle and given food and tap water ad libitum during all the experimental period.

After seven days of experimentation three rats of APAP control group were sacrificed to examine the liver and spleen tissues to confirm inflammation and oxidation status by microscopic examination. At the end of the experimental period (four weeks) rats were anesthetized using diethyl ether anesthesia after overnight fasting. Blood samples were 
collected from the hepatic portal vein and serum was separated for analysis. Then rats sacrificed and abdomen was opened at greater curvature as liver and spleen were removed to be examined microscopically.

2.4. Biochemical analysis: - Whole blood was analyzed for the immediate determination of non enzymatic antioxidant GSH according to Beutler et al. (1963). Serum was analyzed for CAT activity according to Aebi (1984), GST activity according to Habig and Jakoby (1974), GR activity according to Goldberg and Spooner (1983), TNF- $\alpha$ and IL1b levels using Koma Biotech kit, MPO activity using Biosource kit, IgG and IgM levels using Biocientifica kit, ?-GT activity according to Szasz and Persijn (1974), AST and ALT activities using kits of Biodiagnostic. Hepatic tissue was analyzed for determination of MDA level according to Draper and Hadley (1990), NO concentration according to Montgomery and Dymock (1961) and protein carbonyl group content according to Reznick and Packer (1994).

2.5. Microscopical examination:-Liver and spleen were dissected out and fixed instantaneously in $10 \%$ formalin solution for $24 \mathrm{~h}$. Paraffin blocks were prepared and $5 \mu \mathrm{m}$ thick sections were subjected to microscopic examination, Hematoxylin and Eosin stains (H \& E) were used with magnification power 40 or 200 (Kiernan, 2001).

2.6. Statistical analysis: - Results analyzed using the SPSS software (version 16). The results were expressed as means \pm standard deviation (SD). Differences between treated groups were analyzed by one way analysis of variance (ANOVA; F-test) and least significant difference (L.S.D) according to Levesque (2007).

\section{Results}

Effect of M. oleifera water or ethanolic extracts administration on hepatic MDA, NO and PCG levels in APAP intoxicated rats

Table (1) showed that APAP acts as a potent oxidant and caused a state of oxidative stress by causing a massive increase the level of oxidative biomarkers. Hepatic MDA, NO and PCG were significantly increased and recorded 5.40 $\pm 0.03 \mu \mathrm{mol} / \mathrm{g}, 36.12 \pm 0.46 \mu \mathrm{mol} / \mathrm{g}$, and $17.85 \pm 0.13 \mathrm{nmol} / \mathrm{mg}$ respectively in APAP control group. On the other hand, the results revealed that $M$. oleifera water and ethanolic extracts have potent antioxidants and nutrients which improved the oxidative biomarkers levels. The best improvements were found in $400 \mathrm{mg}$ ethanolic extract treated group and the values recorded $2.42 \pm 0.02 \mu \mathrm{mol} / \mathrm{g}$, $23.14 \pm 0.91 \mu \mathrm{mol} / \mathrm{g}$, and $6.71 \pm 0.06 \mathrm{nmol} / \mathrm{mg}$ for hepatic MDA, NO and PCG respectively. 
Effect of M. oleifera water or ethanolic extracts administration on serum CAT, GR, GST activities and GSH level in APAP intoxicated rats

Table (2) showed that APAP acts as a potent oxidant which caused a state of oxidative stress manifested by a massive decrease in the activities of serum antioxidant enzymes, CAT, GR, and GST as well as depletion of the blood non enzymatic antioxidant GSH level in APAP control group when compared with healthy control group. While we observed that water and ethanolic extracts contain potent antioxidants caused a noticeable improvement in the level of antioxidant enzymes as well as nonenzymatic antioxidants as there was a significant increase in serum CAT, GR, GST activities as well as blood GSH level in water and ethanolic administered APAP groups when compared with APAP control group.

Effect of M. oleifera water or ethanolic extracts administration on serum ALT, AST and VGT activities in APAP intoxicated rats

Table (3) showed that APAP induces hepatotoxicity causing degeneration of hepatocytes which causes a massive increase in the level of liver function enzymes activities. Serum ALT, AST and $\gamma$ GT were significantly increased and recorded $84.58 \pm 2.43 \mathrm{U} / \mathrm{ml}, 73.37 \pm 2.31 \mathrm{U} / \mathrm{ml}$, and $44.26 \pm 1.45 \mathrm{U} / \mathrm{I}$ respectively in APAP control group. But water and ethanolic extracts contain potent antioxidants that have a hepatoprotective effect and thus caused a noticeable improvement in the level of liver function enzymes in APAP treated groups when compared with APAP control group.

Effect of M. oleifera water or ethanolic extracts administration on serum TNF- $\alpha$, IL-16 levels and MPO activity in APAP intoxicated rats

APAP toxicity induces activation of inflammatory cells causing a massive increase in the level of serum TNF- $\alpha$ and IL-1 $\beta$, as well as MPO activity in APAP control group when compared with healthy control group as shown in table (4). Mean while water and ethanolic extracts have an anti-inflammatory activity and thus caused a noticeable improvement in the level of inflammatory markers in APAP treated groups when compared with APAP control group.

Effect of M. oleifera water or ethanolic extracts administration on serum IgG and IgM levels in APAP intoxicated rats

The suppression of the immune system by APAP administration is recorded in table (5) as a huge decrease in the level of immunoglobulins. Serum immunoglobulins IgG and IgM were significantly decreased and recorded $464.82 \pm 2.94 \mathrm{mg} / \mathrm{dl}$ and $64.33 \pm 2.60 \mathrm{mg} / \mathrm{dl}$ respectively 
in APAP control group. On the other hand water and ethanolic extracts have an immunomodulatory activity and thus caused a noticeable improvement in the level of immunoglobulins in APAP treated groups when compared with APAP control group. The highest values were found in $400 \mathrm{mg}$ ethanolic extract treated group and recorded $715.96 \pm 2.63 \mathrm{mg} / \mathrm{dl}$ and $176.49 \pm 2.31 \mathrm{mg} / \mathrm{dl}$ for serum IgG and IgM respectively.

Effect of M. oleifera water or ethanolic extracts administration on microscopical examination of the liver and spleen in APAP intoxicated rats

The results of microscopical examination of liver and spleen illustrated in figures (1-8) showed the degenerative changes caused by APAP and the curative role of water and ethanolic extract on degenerated hepatocytes and splenic tissues. APAP caused multiple foci of spotty parenchymal mono-nuclear inflammation and focal parenchymal granuloma formation. The granuloma is made up of histocytes and lymphocytes with minimal fibrous tissue in the liver. APAP also caused severely widened red pulp, congested sinusoid and markedly atrophied lymphoid follicles with extreme variability of the size in the spleen. On the other hand water and ethanolic extract improved the architecture of hepatic and spleen tissues.

Table (1): Effect of $M$. oleifera water or ethanolic extracts administration on hepatic MDA, NO and PCG levels in APAP intoxicated rats:

\begin{tabular}{|c|c|c|c|}
\hline $\begin{array}{ll}\text { Parameters } & \text { Groups } \\
\end{array}$ & $\begin{array}{c}\text { MDA } \\
(\mu \mathrm{mol} / \mathrm{g})\end{array}$ & $\begin{array}{c}\mathrm{NO} \\
(\mu \mathrm{mol} / \mathrm{g})\end{array}$ & $\begin{array}{c}\text { PCG } \\
\text { (nmol/mg) }\end{array}$ \\
\hline Healthy control rats & $1.91 \pm 0.064^{h}$ & $16.29 \pm 1.00^{\mathrm{g}}$ & $6.02 \pm 0.03^{h}$ \\
\hline Intoxicated control rats & $5.40 \pm 0.03^{\mathrm{a}}$ & $36.12 \pm 0.46^{\mathrm{a}}$ & $17.85 \pm 0.13^{\mathrm{a}}$ \\
\hline $\begin{array}{l}\text { Intoxicated rats supplemented } \\
\text { with } 200 \mathrm{mg} \text { water extract }\end{array}$ & $4.72 \pm 0.01^{b}$ & $30.84 \pm 0.26^{b}$ & $15.47 \pm 0.08^{b}$ \\
\hline $\begin{array}{l}\text { Intoxicated rats supplemented } \\
\text { with } 300 \mathrm{mg} \text { water extract }\end{array}$ & $4.02 \pm 0.01^{d}$ & $27.12 \pm 0.29^{d}$ & $13.02 \pm 0.06^{\mathrm{d}}$ \\
\hline $\begin{array}{l}\text { Intoxicated rats supplemented } \\
\text { with } 400 \mathrm{mg} \text { water extract }\end{array}$ & $3.41 \pm 0.01^{\mathrm{e}}$ & $26.43 \pm 1.04^{d}$ & $10.58 \pm 0.05^{\mathrm{e}}$ \\
\hline $\begin{array}{l}\text { Intoxicated rats supplemented } \\
\text { with } 200 \mathrm{mg} \text { ethanolic extract }\end{array}$ & $4.41 \pm 0.01^{c}$ & $30.0 \pm 0.70^{c}$ & $13.64 \pm 0.06^{c}$ \\
\hline $\begin{array}{l}\text { Intoxicated rats supplemented } \\
\text { with } 300 \mathrm{mg} \text { ethanolic extract }\end{array}$ & $3.30 \pm 0.01^{f}$ & $24.91 \pm 0.27^{\mathrm{e}}$ & $10.21 \pm 0.04^{f}$ \\
\hline $\begin{array}{l}\text { Intoxicated rats supplemented } \\
\text { with } 400 \mathrm{mg} \text { ethanolic extract }\end{array}$ & $2.42 \pm 0.02^{\mathrm{g}}$ & $23.14 \pm 0.91^{f}$ & $6.71 \pm 0.06^{g}$ \\
\hline L.S.D (p $\leq 0.05)$ & 0.0368 & 0.8134 & 0.0823 \\
\hline
\end{tabular}

- Values are expressed as means $\pm S . D, n=10$.

- There was no significant difference between means have the same alphabetical superscripts letter in the same column. $(p \leq 0.05)$.

- Intoxicated rats consumed APAP dose of ( $1 \mathrm{~g} / \mathrm{kg}$ body weight). 
Table (2): Effect of $M$. olifera water or ethanolic extracts administration on serum CAT, GR, GST activities and blood GSH level in APAP intoxicated rats:

\begin{tabular}{|c|c|c|c|c|}
\hline $\begin{array}{l}\text { Groups } \\
\text { Parameters }\end{array}$ & $\begin{array}{l}\text { CAT } \\
\text { (U/I) }\end{array}$ & $\begin{array}{l}G R \\
(U / I)\end{array}$ & $\begin{array}{l}\text { GST } \\
(U / I)\end{array}$ & $\begin{array}{c}\text { GSH } \\
(\mathrm{mg} / \mathrm{dl})\end{array}$ \\
\hline Healthy control rats & $102.12 \pm 1.46^{\mathrm{a}}$ & $77.86 \pm 1.87^{\mathrm{a}}$ & $72.52 \pm 2.45^{a}$ & $80.98 \pm 2.13^{\mathrm{a}}$ \\
\hline Intoxicated control rats & $57.50 \pm 1.87^{h}$ & $46.42 \pm 1.38^{g}$ & $34.97 \pm 2.45^{g}$ & $49.26 \pm 0.53^{h}$ \\
\hline $\begin{array}{l}\text { Intoxicated rats supplemented } \\
\text { with } 200 \mathrm{mg} \text { water extract }\end{array}$ & $64.75 \pm 2.09^{g}$ & $49.02 \pm 1.23^{f}$ & $37.31 \pm 1.99^{f}$ & $55.46 \pm 0.61^{g}$ \\
\hline $\begin{array}{c}\text { Intoxicated rats supplemented } \\
\text { with } 300 \mathrm{mg} \text { water extract }\end{array}$ & $73.46 \pm 2.15^{\mathrm{e}}$ & $54.13 \pm 1.07^{d}$ & $40.43 \pm 1.32^{\mathrm{e}}$ & $60.24 \pm 0.56^{\mathrm{e}}$ \\
\hline $\begin{array}{c}\text { Intoxicated rats supplemented } \\
\text { with } 400 \mathrm{mg} \text { water extract }\end{array}$ & $76.41 \pm 1.74^{d}$ & $57.35 \pm 1.43^{c}$ & $45.24 \pm 2.11^{d}$ & $62.49 \pm 0.73^{\mathrm{d}}$ \\
\hline $\begin{array}{l}\text { Intoxicated rats supplemented } \\
\text { with } 200 \mathrm{mg} \text { ethanolic extract }\end{array}$ & $70.87 \pm 1.77^{f}$ & $52.49 \pm 1.54^{\mathrm{e}}$ & $40.07 \pm 1.66^{e}$ & $58.04 \pm 0.52^{\dagger}$ \\
\hline $\begin{array}{l}\text { Intoxicated rats supplemented } \\
\text { with } 300 \mathrm{mg} \text { ethanolic extract }\end{array}$ & $81.95 \pm 1.41^{c}$ & $58.64 \pm 1.09^{c}$ & $48.91 \pm 1.72^{c}$ & $66.62 \pm 0.74^{c}$ \\
\hline $\begin{array}{l}\text { Intoxicated rats supplemented } \\
\text { with } 400 \mathrm{mg} \text { ethanolic extract }\end{array}$ & $89.20 \pm 0.92^{b}$ & $67.5 \pm 1.203^{b}$ & $56.41 \pm 2.05^{b}$ & $71.17 \pm 0.56^{b}$ \\
\hline L.S.D (p $\leq 0.05)$ & 2.009 & 1.610 & 2.342 & 1.107 \\
\hline
\end{tabular}

- Values are expressed as means $\pm S . D, n=10$.

- There was no significant difference between means have the same alphabetical superscripts letter in the same column. ( $p \leq 0.05)$.

- Intoxicated rats consumed APAP dose of ( $1 \mathrm{~g} / \mathrm{kg}$ body weight).

Table (3): Effect of $M$. oleifera water or ethanolic extracts administration on serum ALT, AST and $y$ GT activities in APAP intoxicated rats:

\begin{tabular}{|c|c|c|c|}
\hline Parameters $\quad$ Groups & $\begin{array}{c}\text { ALT } \\
(\mathrm{U} / \mathrm{ml})\end{array}$ & $\begin{array}{c}\text { AST } \\
(\mathrm{U} / \mathrm{ml})\end{array}$ & $\begin{array}{l}\text { VGT } \\
(U / I)\end{array}$ \\
\hline Healthy control rats & $29.03 \pm 1.85^{g}$ & $23.06 \pm 1.56^{h}$ & $9.93 \pm 0.46^{g}$ \\
\hline Intoxicated control rats & $84.58 \pm 2.43^{\mathrm{a}}$ & $73.37 \pm 2.31^{\mathrm{a}}$ & $44.26 \pm 1.45^{a}$ \\
\hline $\begin{array}{l}\text { Intoxicated rats supplemented } \\
\text { with } 200 \mathrm{mg} \text { water extract }\end{array}$ & $73.93 \pm 2.61^{b}$ & $64.56 \pm 2.170^{b}$ & $36.01 \pm 1.40^{b}$ \\
\hline $\begin{array}{c}\text { Intoxicated rats supplemented } \\
\text { with } 300 \mathrm{mg} \text { water extract }\end{array}$ & $63.93 \pm 2.73^{c}$ & $49.20 \pm 1.38^{d}$ & $30.09 \pm 1.58^{c}$ \\
\hline $\begin{array}{l}\text { Intoxicated rats supplemented } \\
\text { with } 400 \mathrm{mg} \text { water extract }\end{array}$ & $58.19 \pm 1.47^{d}$ & $45.08 \pm 1.42^{\mathrm{e}}$ & $27.06 \pm 1.62^{d}$ \\
\hline $\begin{array}{l}\text { Intoxicated rats supplemented } \\
\text { with } 200 \mathrm{mg} \text { ethanolic extract }\end{array}$ & $66.22 \pm 3.07^{c}$ & $55.12 \pm 1.35^{c}$ & $35.80 \pm 1.16^{b}$ \\
\hline $\begin{array}{l}\text { Intoxicated rats supplemented } \\
\text { with } 300 \mathrm{mg} \text { ethanolic extract }\end{array}$ & $52.20 \pm 1.673^{\mathrm{e}}$ & $42.15 \pm 0.97^{f}$ & $21.51 \pm 1.96^{\mathrm{e}}$ \\
\hline $\begin{array}{l}\text { Intoxicated rats supplemented } \\
\text { with } 400 \mathrm{mg} \text { ethanolic extract }\end{array}$ & $43.86 \pm 1.17^{f}$ & $32.40 \pm 0.58^{g}$ & $19.19 \pm 1.38^{f}$ \\
\hline L.S.D (p $\leq 0.05)$ & 2.591 & 1.8263 & 1.3533 \\
\hline
\end{tabular}

- Values are expressed as means $\pm S . D, n=10$.

- There was no significant difference between means have the same alphabetical superscripts letter in the same column. ( $\mathrm{p} \leq 0.05)$.

- Intoxicated rats consumed APAP dose of ( $1 \mathrm{~g} / \mathrm{kg}$ body weight). 
Table (4): Effect of $M$. oleifera water or ethanolic extracts administration on serum TNF- $\alpha$, IL-1 $\beta$ levels and MPO activity in APAP intoxicated rats:-

\begin{tabular}{|c|c|c|c|}
\hline $\begin{array}{ll}\text { Parameters } & \text { Groups } \\
\end{array}$ & $\begin{array}{l}\text { TNF- } \alpha \\
(\mathrm{pg} / \mathrm{ml})\end{array}$ & $\begin{array}{l}\text { IL-1 } \beta \\
(\mathrm{pg} / \mathrm{ml})\end{array}$ & $\begin{array}{l}\text { MPO } \\
(\mathrm{ng} / \mathrm{ml})\end{array}$ \\
\hline Healthy control rats & $27.22 \pm 0.59^{g}$ & $50.63 \pm 0.54^{h}$ & $0.96 \pm 0.02^{h}$ \\
\hline Intoxicated control rats & $77.12 \pm 2.11^{\mathrm{a}}$ & $91.01 \pm 0.76^{a}$ & $9.99 \pm 0.01^{\mathrm{a}}$ \\
\hline $\begin{array}{l}\text { Intoxicated rats supplemented } \\
\text { with } 200 \mathrm{mg} \text { water extract }\end{array}$ & $64.38 \pm 1.70^{b}$ & $84.51 \pm 0.76^{b}$ & $8.88 \pm 0.08^{b}$ \\
\hline $\begin{array}{l}\text { Intoxicated rats supplemented } \\
\text { with } 300 \mathrm{mg} \text { water extract }\end{array}$ & $56.25 \pm 2.39^{d}$ & $77.38 \pm 0.66^{d}$ & $6.78 \pm 0.37^{d}$ \\
\hline $\begin{array}{l}\text { Intoxicated rats supplemented } \\
\text { with } 400 \mathrm{mg} \text { water extract }\end{array}$ & $47.76 \pm 1.97^{\mathrm{e}}$ & $69.18 \pm 1.31^{\mathrm{e}}$ & $5.73 \pm 0.23^{\mathrm{e}}$ \\
\hline $\begin{array}{l}\text { Intoxicated rats supplemented } \\
\text { with } 200 \mathrm{mg} \text { ethanolic extract }\end{array}$ & $61.20 \pm 1.80^{c}$ & $78.88 \pm 0.61^{c}$ & $7.32 \pm 0.22^{c}$ \\
\hline $\begin{array}{c}\text { Intoxicated rats supplemented } \\
\text { with } 300 \mathrm{mg} \text { ethanolic extract }\end{array}$ & $45.89 \pm 1.97^{\mathrm{e}}$ & $66.65 \pm 1.19^{f}$ & $4.63 \pm 0.31^{f}$ \\
\hline $\begin{array}{l}\text { Intoxicated rats supplemented } \\
\text { with } 400 \mathrm{mg} \text { ethanolic extract }\end{array}$ & $33.96 \pm 0.45^{f}$ & $57.17 \pm 0.51^{g}$ & $2.87 \pm 0.09^{g}$ \\
\hline L.S.D (p $\leq 0.05)$ & 2.238 & 1.084 & 0.272 \\
\hline
\end{tabular}

- Values are expressed as means $\pm S . D, n=10$.

- There was no significant difference between means have the same alphabetical superscripts letter in the same column. ( $p \leq 0.05)$.

- Intoxicated rats consumed APAP dose of $(1 \mathrm{~g} / \mathrm{kg}$ body weight).

Table (5): Effect of $M$. oleifera water or ethanolic extracts administration on serum IgG and IgM levels in APAP intoxicated rats:

\begin{tabular}{|c|c|c|}
\hline 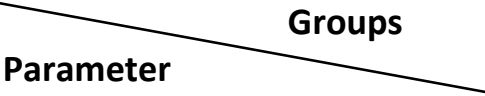 & $\begin{array}{l}\operatorname{lgG} \\
(\mathrm{mg} / \mathrm{dl})\end{array}$ & $\underset{(\mathrm{lgM} / \mathrm{dl})}{\mathrm{IgM}}$ \\
\hline Healthy control rats & $849.06 \pm 5.42^{\mathrm{a}}$ & $196.10 \pm 1.28^{\mathrm{a}}$ \\
\hline Intoxicated control rats & $464.82 \pm 2.94^{h}$ & $64.33 \pm 2.60^{h}$ \\
\hline $\begin{array}{c}\text { Intoxicated rats supplemented } \\
\text { with } 200 \mathrm{mg} \text { water extract }\end{array}$ & $524.78 \pm 2.75^{g}$ & $86.30 \pm 2.47^{g}$ \\
\hline $\begin{array}{l}\text { Intoxicated rats supplemented } \\
\text { with } 300 \mathrm{mg} \text { water extract }\end{array}$ & $569.65 \pm 1.52^{\mathrm{e}}$ & $114.83 \pm 2.78^{\mathrm{e}}$ \\
\hline $\begin{array}{l}\text { Intoxicated rats supplemented } \\
\text { with } 400 \mathrm{mg} \text { water extract }\end{array}$ & $619.5 \pm 2.09^{d}$ & $126.01 \pm 2.63^{d}$ \\
\hline $\begin{array}{l}\text { Intoxicated rats supplemented } \\
\text { with } 200 \mathrm{mg} \text { ethanolic extract }\end{array}$ & $557.23 \pm 2.38^{f}$ & $105.71 \pm 3.32^{f}$ \\
\hline $\begin{array}{l}\text { Intoxicated rats supplemented } \\
\text { with } 300 \mathrm{mg} \text { ethanolic extract }\end{array}$ & $626.19 \pm 2.88^{c}$ & $146.08 \pm 3.52^{c}$ \\
\hline $\begin{array}{l}\text { Intoxicated rats supplemented } \\
\text { with } 400 \mathrm{mg} \text { ethanolic extract }\end{array}$ & $715.96 \pm 2.63^{b}$ & $176.49 \pm 2.31^{b}$ \\
\hline L.S.D (p $\leq 0.05)$ & 3.535 & 3.143 \\
\hline
\end{tabular}

- Values are expressed as means $\pm S . D, n=10$.

- There was no significant difference between means have the same alphabetical superscripts letter in the same column. $(p \leq 0.05)$.

- Intoxicated rats consumed APAP dose of ( $1 \mathrm{~g} / \mathrm{kg}$ body weight). 


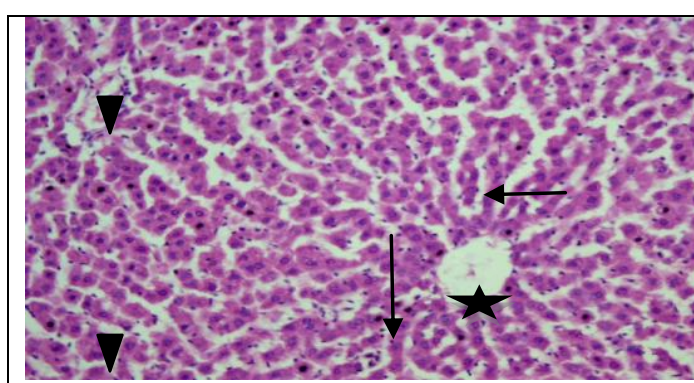

Fig. (1):- Photomicrograph of a section of a liver tissue from healthy rat control group shows preserved architecture. $(\downarrow)$ is the central vein, ( $)$ the hepatocytes, and ( ) is the portal tract.(H. \& E. x 200).

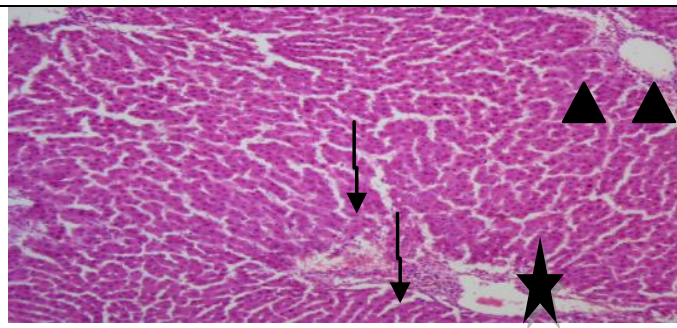

Fig. (3 ):- Photomicrograph of a section in the rat liver of $\mathbf{4 0 0} \mathrm{mg}$ water extract treated APAP group showing wide congested central vein ( ), pe, central mono-nuclear \$potty inflammation( ) and portal tracty flammation ( ).(H\& E. $x$ 200).

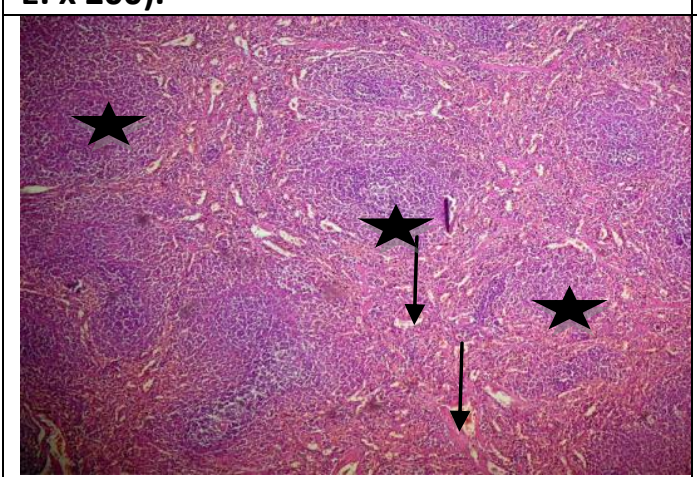

Fig. (5):-Photomicrograph of a section in the rat spleen of healthy control group shows preserved architecture. The blood sinusoids are slightly congested ( ). The lymphoid follicles are unremarkable () (H. \&. x40).

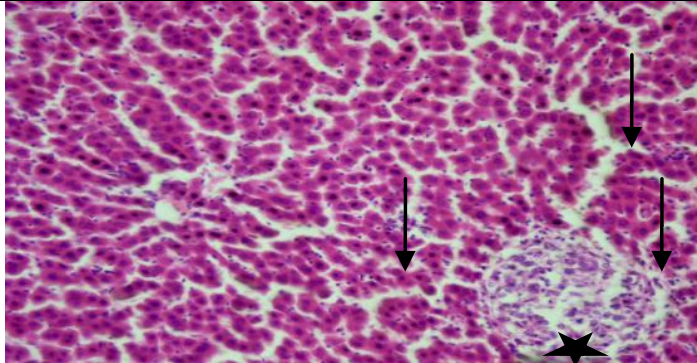

Fig. (2):-Photomicrograph of a section in the rat liver of APAP control group showing multiple foci of spotty parenchymal mononuclear inflammation $(\downarrow)$ and focal parenchymal granuloma formation. The granuloma is made up of histocytes and lymphocytes with minimal fibrous tissue ) (H\& E. x 200).

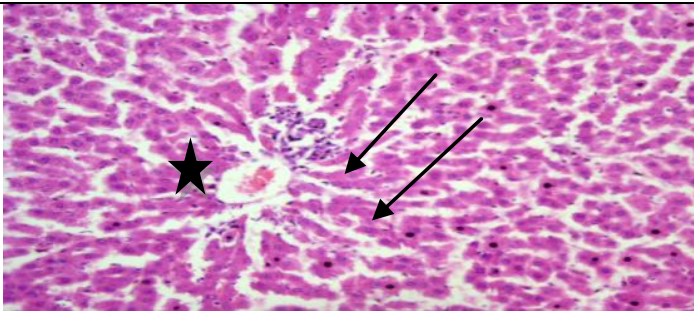

Fig. (4):-Photomicrograph of a section in the rat liver of $400 \mathrm{mg}$ ethanolic extract treated APAP group showing preserved architecture, slightly congested central vein ( W)and focal parenchymal mononuclear necro-inflammatory infiltrate ) .(H\& E. x 200).

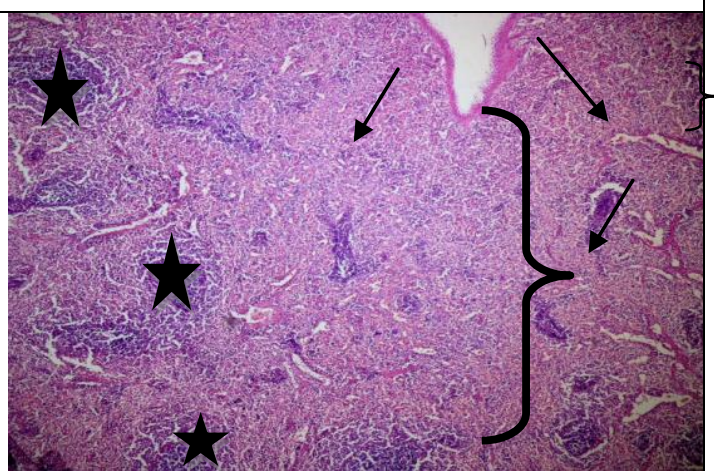

Fig. (6):-Photomicrograph of a section in the rat spleen of APAP control grpup showing severely widened red pulp $(\downarrow)$, congested sinusoid( $\}$ ) and markedly atrophied lymphoid follicles with extreme variability of the size( ).(H. \& E Y 40) 


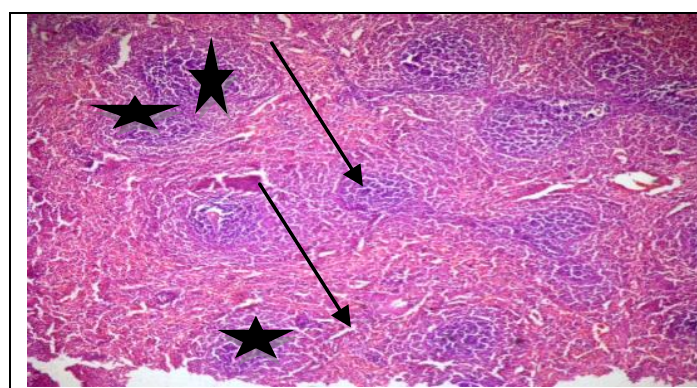

Fig.(7) :-Photomicrograph of a section in the rat spleen of $\mathbf{4 0 0} \mathbf{~ m g}$ water extract treated APAP group showing less congested widened blood sinusoid( than group (4) and the lymphoid follicles are variably sized and slightly dispersed ( ).(H.\& E $、$ (40) .

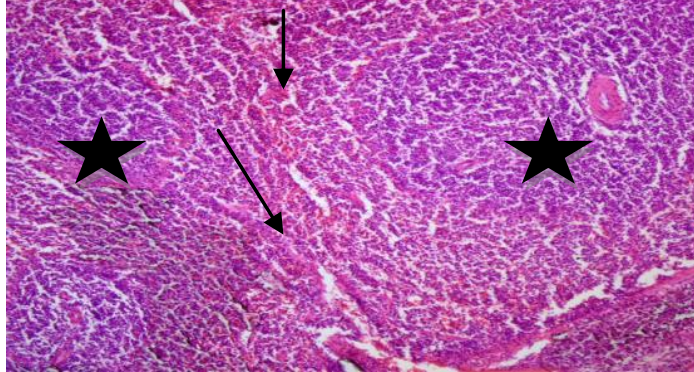

Fig.(8):- Photomicrograph of a section in the rat spleen of $\mathbf{4 0 0} \mathbf{~ m g}$ ethanolic extract treated APAP group in which the splenic tissue showed preserved architecture. The blood sinusojds are more congested than group (1) ( ). The (ymphoid follicles are unremarkable ( ).(H. \& E. x40).

\section{Discussion}

Oxidative stress is caused by an imbalance between the production of ROS or oxygen free radicals and a biological system's ability to readily detoxify the reactive intermediates or easily repair the resulting damage leading to important health implications (Rainjbar et al., 2005). APAP toxic metabolite NAPQI forms a covalent adduct with mitochondrial proteins having thiol groups and plasma membrane proteins involved in calcium homeostasis. Disruption of calcium homeostasis may result in the activation of many membrane damaging enzymes like ATPases, phospholipases, proteases and endonucleases, disruption of mitochondrial metabolism and ATP synthesis and damage of microfilaments used to support cell structure. Significant amount of evidence has pointed to the potential involvement of oxidative stress in APAP toxicity (Singh et al., 2011b). A rapidly growing number of published studies have shown that water, hydroalcohol, or alcohol extracts of $M$. oleifera leaves possess a wide range of additional biological activities including antioxidant, tissue protective (liver, kidneys, heart, testes, and lungs), analgesic, antiulcer, antihypertensive, radioprotective, and immunomodulatory actions. A wide variety of polyphenols and phenolic acids as well as flavonoids, glucosinolates, and possibly alkaloids is believed to be responsible for that observed effects (Stohs and Hartman, 2015).

Results of the current study showed significant increase in MDA,NO, and PCG levels in APAP hepatotoxicated rats compared to healthy controls, meanwhile there was a significant decrease in the same parameters among rats which supplemented with water as well as ethanolic extract of M.olifera table (1).These results were found to be in accordance with Olatosin et al.(2014); Hamza and Al-Harbi (2015); Dwivedi et al. (2015) and Karthivashan 
et al. (2016). They explained that, the elevation in thiobarbituric acid reactive substance level is an indicator of lipid peroxidation, which has been suggested to be closely related to APAPinduced tissue damage. Also and supporting our findings, Abdel-Zaher et al.(2008) suggested that the generation of ROS appears as an early event which precedes intracellular glutathione depletion and cell damage in APAP hepatotoxicity. The superoxide formation may promote peroxynitrite generation and protein nitration that may further result into oxidative damage to proteins, DNA and lipids. Excess ROS can promote protein oxidation, forming protein carbonyls which have been described as reliable marker to estimate the degree of oxidant-mediated protein damage (Margetis et al., 2009). In the same line of our results Alantary et al. (2014) reported that APAP toxicity increased both hepatic and plasma MDA levels as well as plasma NO level in APAP treated rats in comparison with healthy control rats due to a state of oxidative stress and inflammation leading to activation of inducible nitric oxide synthase activity (iNOS) causing massive increase in NO synthesis and lipid peroxidation leading to increased formation of MDA.

On the other hand water and ethanolic extract of $M$. oleifera leaves decreased the level of MDA, NO, and PCG in APAP treated groups as compared with APAP control group due to antioxidant activity of leaves extract.

The leaves of $M$. oleifera are rich in flavonoids. Flavonoids are phenolic substances which have antioxidant property (Sharma and Rajani, 2011). The M.oleifera leaf is a rich source of flavonoids like quercetin, kaempferol, catechin, epicatechin, rutin etc, all are potent antioxidants. Further, previous studies have reported the protective action of flavonoids against oxidative stress induced cellular damage. Flavonoids can exert their antioxidant activity by various mechanisms, e.g., by scavenging or quenching free radicals, by chelating metal ions, or by inhibiting enzymatic systems responsible for free radical generation (Lukacinova et al., 2008).The antioxidant property also can be due to the presence of carotenoids, alkaloids, proanthocyanidins in this plant (Mishra et al., 2007).

Our observations were matched with that of Akomolafe et al. (2012); Saalu et al. (2012) and Eshak and Osman (2013) who demonstrated the free radical scavenging ability of water extract of $M$. oleifera leaves in several in vitro systems, and also showed that the extract inhibited lipid peroxidation.

Our results were supported by Fakurazi et al. (2012); Sikder et al. (2013) and Karthivashan et al. (2016) who stated that ethanolic extract of $M$. oleifera leaves has a 
strong potential as curative and therapeutic agent against oxidative stress originating from any source which warrants further in vitro and in vivo experiments.

In the current study, CAT, GR and GST activities as well as GSH level were significantly decreased in APAP control rats as a result of the oxidative stress table (2). These results were found to be in accordance with many studies such as that of Dwivedi et al. (2015) and Karthivashan et al. (2016).

Dwivedi et al. (2015) confirmed that, APAP toxicity caused a significant decrease in the level of non-enzymatic antioxidant GSH with depletion of antioxidant enzymes activities due to oxidative stress and lipid peroxidation.

Also, Karthivashan et al. (2016) illustrated that, APAP administration to mice was associated with oxidative stress and depletion of CAT activity.

M. oleifera leaves contain different classes of phytocompounds, vitamins and carotenoids and these compounds mainly contribute to the antioxidant properties as well as other biological activities. The main antioxidant activity that has been associated with phenolic content ability to scavenge free radical formation. Phenolic compounds are known for their potent antioxidant properties. Phenolics are the main dietary antioxidants and possess higher in vitro antioxidant capacity than the essential vitamins and carotenoids. Certain phenolic compounds also may induce production of glutathione-S-transferase and other antioxidant enzymes (Verma et al., 2009).

Our results showed a significant increase in the activity of serum liver enzymes ALT, AST, and $\gamma \mathrm{GT}$ as a result of the oxidative stress caused by APAP toxicity that lead to degeneration of hepatocytes as shown in table (3) and figure (2). Our results were supported by Alantary et al. (2014); Hamza and Al-Harbi (2015) and Dwivedi et al. (2015). They showed that during liver injury caused via overdose of APAP, the transport function of hepatocytes gets disturbed and resulting in the leakage of the plasma membrane, thus causing an increase serum hepatic enzyme activities.

M. oleifera leaves are rich in antioxidants, polyphenols and flavonoids that have a heaptoprotective activity that decrease the activity of liver function enzymes in water and ethanolic extract APAP treated groups table (3). Our results were confirmed by Saalu et al. (2012) and Bahr and Farouk (2016) who reported that administration of M.oleifera leaves water extract decreases significantly ALT, AST, and $\gamma \mathrm{GT}$ enzyme activities attributed to the stabilizing ability of the cell membrane preventing enzymes leakages as well as 
hepatoprotective activity. Also Fakurazi et al. (2012); Eshak and Osman (2013) and El-bakry et al. (2016) supported our results as they showed that decreased ALT, AST, and YGT activities after administration of $M$. oleifera leaves ethanolic extract in APAP toxicated rats due to reduction in the damage of parenchymal and mitochondrial sites of the liver where these enzymes are present.

Our results revealed that APAP overdose caused a significant increase in TNF- $\alpha$, IL-1 $\beta$ levels and MPO activity in toxicated rats as a result of inflammation and oxidative stress table (4). Our results were forced by Dong et al. (2014); Dwivedi et al. (2015) and Karthivashan et al. (2016). They showed that APAP intoxication induces oxidative stress, which further triggers a secondary inflammatory cascade associated with cytokine release from Kupffer cells. Pro-inflammatory cytokines like TNF- $\alpha$ and IL-1 $\beta$ are prominently reported in APAP-induced hepato-renal toxicity. They are engaged in massive tubular infiltration of leukocytes, thereby inducing a sterile inflammatory environment and further exaggerating tissue damage. They also explained that high activity of MPO associated with increased NO production which was used to demonstrate an acute inflammatory process as observed after the liver injury induced by APAP. This is confirmed by inflammatory hepatic tissues, including the presence of moderate infiltration of neutrophils in the liver of APAP treated groups (figure 2).

M. oleifera has health promoting bioactive and nutritive components that increase its potential as a natural supplement in treating disease. Among the many positive benefits, it has immune modulating, antioxidant and anti-inflammatory properties (Fahey, 2005 and Muangnoi et al., 2011). Our results were in agreement with Bahr and Farouk (2016) who demonstrated that $M$. oleifera water extract have phenol and flavonoids content which have anti-inflammatory activity and decreased MPO activity significantly in toxicated rats. Our results go hand in hand with $\mathbf{A h m e d}$ et al. (2014) who explained that the active ingredients of the ethanolic extract of $M$. oleifera have a strong anti-inflammatory effect which are responsible for inhibition of adipocytokines levels like TNF- $\alpha$ and IL-1. Also our results were similar to that of Karthivashan et al. (2016) who showed that M. oleifera ethanolic extract has anti-inflammatory activity and ability to suppress production of pro-inflammatory markers produced as a result of APAP toxicity like TNF- $\alpha$ and IL-1

The findings of this study revealed that APAP caused a significant decrease in the immunoglobulins like $\operatorname{lgG}$ and $\lg M$ as a result of oxidative stress, tissues injury and 
inflammation which affect the immune system table (5). Our results were in agreement with Ekam et al. (2012) who showed that administration of APAP statistically decreased serum total protein, and globulin levels in the APAP group compared to that of the normal control group. This decrease in serum protein in hepatotoxicity states simply indicates the presence of para- proteins or decreased antibody production.

Nutrients affect immune function by directly acting within the lymphoid system, or indirectly by affecting cellular material or other organ systems that act as immune regulators. The presence of minerals such as selenium, zinc, iron, manganese and magnesium in the leaf extract may contribute to its immunomodulatory action, since these minerals have been implicated in immune modulation. Our findings were similar to that of Deshmukh et al. (2015) who demonstrated the immunomodulatory activity of both ethanolic and water extracts of $M$. oleifera. But the ethanolic extract had a more potent immunomodulatory activity than the water extract. The immunomodulatory activity may be attributed to the presence of an array of phytochemicals.

APAP caused an observed change on the microscopical examination of the liver and spleen as a result of degeneration and inflammation resulting from oxidative stress and confirmed by increased activities of liver function enzymes while water and ethanolic extract of $M$. oleifera caused a significant improvement in toxicated tissue as a result of the natural antioxidants and cytoprotective ability of $M$. oleifera leaves as shown in figures (1-8).

Our results agree with the results of Kanchana and Sadiq (2011)and Yesmin et al. (2013) who revealed sever conditions including cell swelling, severe inflammation and necrosis in APAP-exposed rats, which was quiet contrasting compared to the control group due to oxidative stress and lipid peroxidation associated with APAP intake. They explained that paracetamol oxidation product NAPQI, bind covalently to sylphydryl groups of protein resulting in cell necrosis and lipid peroxidation induced by the glutathione decrease causing hepatotoxicity.

Our findings were in agreement with that of Lim et al. (2010) who showed that splenic congestion was observed at APAP dose of $140 \mathrm{mg} / \mathrm{kg}$. Also our results were similar to that of Omotoso et al. (2015) who showed that $M$.oleifera water leaf extract has hepatoprotective properties possibly via its chemical constituents. Moreover our results were confirmed also by Fakurazi et al. (2012) who discussed that therapeutic properties of M.oleifera leaf hydroethanolic extract against acute liver injury caused by paracetamol through its potent 
antioxidant activity .Most areas appear to have recovered, hepatocytes well preserved and no area of necrosis. This may be due to the improvement in hepatic architecture disorganization, severe hepatic fatty degeneration together with inflammatory cells infiltration after $M$. oleifera extract administration. It was also reported that the major bioactive compounds of phenolics such as quercetin and kaempferol are responsible for antioxidant activity, anti-inflammatory and anti-arthritic properties of the extract.

In addition the results of Muselin et al. (2010) and Owolabi et al. (2014) were in agreement with the result of this study. They demonstrated that $M$. oleifera leaf extract treat splenic enlargement and necrosis. As well as improved physiological functions of the tissue. M. oleifera has been reported to produce positive effects on the body's immunity and could ameliorate the toxicity on the spleen, thus preventing splenomegaly and splenic hyperplasia.

5.Conclusion: Both daily water and ethanolic extracts administration at the tested doses $(200,300$ and $400 \mathrm{mg} / \mathrm{Kg}$ body weight) to rats exerted an immunomodulatory, antioxidant, hepatoprotective and anti-inflammatory effects which were probably mediated by its strong antioxidants (zeatin, quercetin, beta-sitosterol and kaempferol) as well as minerals and vitamins. Moreover the ethanolic extracts were more effective when administered in the dose level of $(400 \mathrm{mg} / \mathrm{kg})$ due to the highest lipid solubility of these active components.

\section{References}

Abdel-zaher A.O., Abdel-Hady R.H., Mahmoud M.M. and Farrag M.M. (2008):The Potential Protective Role of Alpha-lipoic Acid Against Acetaminophen Induced Hepatic and Renal Damage. J Toxicol., 243:261-270.

Aebi, H.(1984) : Catalase in Vitro. Methods Enzymol., 105:121-126.

Ahmed H.H., Metwally F. M., Rashad H., Zaazaa A. M., Ezzat S. M. and Salama M. M. (2014): M. oleifera Offers a Multi-Mechanistic Approach for Management of Obesity in Rats. Int. J. Pharma. Sci. Rev. Res., 29(2):98-106.

Akomolafe S. F. , Oboh G., Akindahunsi A. A., Akinyemi A. J. and Adeyanju O. (2012): Inhibitory Effect of Aqueous Extract of $M$. oleifera and Newbuoldia laevis Leaves on Ferrous Sulphate and Sodium Nitroprusside Induced Oxidative Stress in Rat's Testes in Vitro. Open J. of Med. Chem., 2:119-128.

Alantary A.K., Rezk M.Y. and Soliman K.E.A (2014): Protective Role of Ghrelin on APAP Induced Acute Hepatotoxicity in Rats. J. of physiol. and pathophysiol., 5(2):7-14.

Babu V., Gangadevi T. and Subramoniam A. (2003): Antidiabetic Activity of Ethanol Extract of Cassia Kleinii Leaf in Streptozotacin Induced Diabetic Rats and Isolation of an Active Fraction and Toxicity Evaluation of the Extract .Ind.J.Pharma.,35:290. 
Bahr H. I. and Farouk S. M. (2016): Comparative Ameliorative Effect of Basil Oil and M. oleifera on Lornoxicam- Mediated Histological and Biochemical Alterations in Albino Rat Liver. J. Veterinar. Sci. Technol., 7(2):1-11.

Berkovich L., Earon G., Ron I., Rimmon A., Vexler A. and Lev-Ari S. (2013): M. oleifera Aqueous Leaf Extract Down-regulates Nuclear Factor-kappa B and Increases Cytotoxic Effect of Chemotherapy in Pancreatic Cancer Cells.BMC J .of Comp. and Alt. Med., 13:212-219.

Beutler E., Duron O. and Kelly B.M. (1963): Improved Method for the Determination of Blood Glutathione. J. Lab. Clin. Med., 61:882-888.

Deshmukh P., Sharma R. K., Sharma V. and Jain P. (2015): Immunomodulatory Activity of M. oleifera in Albino Rats. J. of Animal Res., 5 (2): 277-281.

Dong D., Xu L., Han X., Yan Q., Xu Y., Yin L., Liu K. and Peng J.(2014): Effects of The Total Saponins From Rosa laevigata Michx Fruit Against Acetaminophen-Induced Liver Damage in Mice via Induction of Autophagy and Suppression of Inflammation and Apoptosis.J. Molecules, 19: 7189-7206.

Draper H.H. and Hadley M. (1990): Malondialdehyde Determination as Index of Lipid Peroxidation. Meth. in Enzymol.,186:421-431.

Dwivedi V. K., Mishra J. and Shrivastava A. (2015): Efficacy Study of Livartho Against APAP Induced Hepatotoxicity in Adult Sprague Dawley Rats. J. Drug Metabol. Toxicol., 5 :2-7.

Ekam V. S., Johnson J. T., Dasofunjo K., Odey M. O. and Anyahara S. E.(2012): Total Protein, Albumin and Globulin Levels Following the Administration of Activity Directed Fractions of Vernonia amygdalina During Acetaminophen Induced Hepatotoxicity in Wistar Rats. Annals of Biol. Res., 3 (12):5590-5594.

El-bakry K., Toson E., Serag M. and Aboser M. (2016): Hepatoprotective Effect of M. oleifera Leaves Extract Against Carbon Tetrachloride- Induced Liver Damage in Rats.World J. of Pharma. and Pharmaceutical Sci., 5(5): 76-89.

Eshak M. G. and Osman H. F.(2013): Role of M. oleifera Leaves on Biochemical and Genetical Alterations in Irradiated Male Rats. Middle-East J. Sci. Res., 16 (10): 1303-1315.

Fahey J.W. (2005): M. oleifera: A Review of The Medical Evidence for Its Nutritional, Therapeutic, and Prophylactic Properties. Part 1, Tree Life J.,: 1-5.

Fakurazi S., Sharifudin S. A. and Arulselvan P.(2012): M. oleifera Hydroethanolic Extracts Effectively Alleviate Acetaminophen-Induced Hepatotoxicity in Experimental Rats through Their Antioxidant Nature. J.Molecules, 17: 8335- 8350.

Goldberg D.M. and Spooner R.J. (1983): Detemination of Glutathione Reductase Activity. Methods of Enzymol. Anal (Bergmeyen, H.V. Ed. ) $3^{\text {rd }}$ ed., 3 :258-265.

Habig W. and Jakoby P.M. (1974): Determination of Glutathione-s-transferase Activity. Biol. Chem., 249: $7130-7139$.

Hamza R. Z. and Al-Harbi M. S. (2015): Amelioration of APAP Hepatotoxicity and Oxidative Stress on Mice Liver with Silymarin and Nigella sativa Extract Supplements. Asian Pac. J. Trop. Biomed. , 5(7): 521-531.

Kanchana N. and Sadiq A. M.(2011):Hepatoprotective Effect of Plumbago Zeylanica on APAP Induced Liver Toxicity in Rats. Inter. J. of Pharma. and Pharmaceutical Sci., 3(1):151-154.

Karthivashan G., Arulselvan P., and Fakurazi S. (2015): Pathways Involved in Acetaminophen Hepatotoxicity With Specific Targets for Inhibition/Downregulation. RSC Advances J., 5: 62040- 62051. 
Karthivashan G., Kura A. U., Arulselvan P., Isa N. Md. and Fakurazi S. (2016): The Modulatory Effect of $M$. oleifera Leaf Extract on Endogenous Antioxidant Systems and Inflammatory Markers in Acetaminophen-Induced Nephrotoxic Mice Model. Peer J. Preprints., 1:2063-2095.

Kiernan J.A. (2001): Histological and Histochemical Methods: Theory And Practice. $3^{\text {rd }}$ ed., Arnold publisher, London, New York and New Delhi: 111-162.

Levesque R. (2007): SPSS Programming and Data Management: A Guide For SPSS and SAS user. $3^{\text {rd }}$ edition .USA.

Lim A. YL., Segarra I., Chakravarthi S., Akram S. and Judson J. P. (2010): Histopathology and Biochemistry Analysis of The Interaction Between Sunitinib and APAP in Mice . J.BMC Pharmacol., 10(14):1-17.

Lukacinova A., Mojzis J., Benacka R., Keller J., Maguth T. and Kurila P.(2008): Preventive Effects of Flavonoids on Alloxan-Induced Diabetes Mellitus in Rats. Acta Vet., 77:175-182.

Mahmood K.T., Mugal T. and Haq I.U. (2010): M. oleifera: A Natural Gift- A Review. J. Pharma. Sci., 2: 775-781

Margetis P.I., Antonelou M.H., Petropoulos I.K., Margaritis L.H. and Papassideri I.S.(2009): Increased Protein Carbonylation of Red Blood Cell Membrane in Diabetic Retinopathy. Exp. Mol. Pathol., 87(1):76-82.

Mishra J., Srivastava R.K., Shukla S.V. and Raghav C.S. (2007): Antioxidants in Aromatic and Medicinal Plants. Sci. Tech. entrepreneur, 7:1-16.

Montgomery H.A. and Dymock J.F. (1961): Determination of Nitrite in Water .J. Analyst., 86: 414-416.

Muangnoi C., Chingsuwanrote P., Praengamthanachoti P., Svasti S. and Tuntipopipat S. (2011): M. oleifera Pod Inhibits Inflammatory Mediator Production by LipopolysaccharideStimulated RAW 264.7 Murine Macrophage Cell Lines. Inflamm. Hamdard Med., 42:37-42.

Muselin F, Trif A., Brezovan D, Stancu A and Snejana PV.(2010):The Consequences of Chronic Exposure to Lead on Liver, Spleen, Lungs and Kidney Architectonics in Rats..J. Toxicol. Sci., 57: 87-94.

(NRC), National Research Council (1995): Nutrient Requirements of Laboratory Animals $4^{\text {th }}$ ed. National Academy Press, Washington, DC.

Neelima, Shami T. C., Shukla N., Mishra P. and Mishra P. (2016): An Overview Literature of Medical Support, Food, Curative and Prophylactic Properties of M. olifera. World J. of Pharmaceutical Res., 5(2):1531-1542.

Olatosin T. M., Akinduko D. S., Uche C. Z. and Bardi J. (2014): Effects of M. oleifera Seed Oil on Acetaminophen-Induced Oxidative Stress and Liver Damage in Wistar Albino Rats. J. of Pharma. and Bio. Sci., 9(2):53-59

Omotoso B. R., Abiodun A. A., ljomone O. M. and Adewole S. O. (2015): Lead-Induced Damage on Hepatocytes and Hepatic Reticular Fibres in Rats; Protective Role of Aqueous Extract of M. oleifera Leaves (Lam). J. of Biosci. and Med., 3:27-35.

Owolabi J. O, Ogunsola A.O. and Fabiyi O. S. (2014): Histological Assessment of M. oleifera Ameliorative Activities on Lead Toxicity in The Spleen of Adult Wistar Rats. World J. Life Sci. and Medical Res., 3(2):63-66.

Paliwal R., Sharma V., and Pracheta S.S. (2011): A Review of Horse Radish Tree (M. oleifera): A Multipurpose Tree with High Economic and Commercial Importance. Asian J.of Biotech., 3 (4): 317-328. 
Pracheta S.S., Sharma V., Paliwal R., Sharma S., and Singh L. (2011):Chemoprotective Activity of Hydro-Ethanolic Extract of Euphorbia Nerrifolia Linn. Leaves Against DENAInduced Liver Carcinogenesis in Mice. Biol. Med., 3: 36-44.

Rainjbar A.H., Solhi F.J., Mashayekhi A., Susanabdi A., Rezaie M. and Abdollahi M.(2005): Oxidative Stress in Acute Human Poisoning With Organophosphorous Insecticides ; A Case Control Study . Environ. Toxicol. Pharmacol., 20:88-91.

Razis A.F.A., Ibrahim M.D. and Kntayya S.B. (2014): Health Benefits of M. oleifera. Asian Pac. J. Cancer Prev., 15: 15-20.

Reznick A.Z. and Packer L. (1994): Determination of protein carbonyl group content Methods Enzymol., 233: 263-357.

Saalu L.C., Ogunlade B., Ajayi G.O., Oyewopo A.O., Akunna G.G. and Gunmodede O.S.(2012): The Hepato-Protective Potentials of $M$. oleifera Leaf Extract on Alcohol-Induced Hepato-Toxicity in Wistar Rat. Am. J. Biotechnol. Mol. Sci., 2(1): 6-14

Sharma V. and Rajani GP.(2011): Evaluation of Caesalpinia pulcherrima Linn. for Antiinflammatory and Antiulcer Activities. Indian J. Pharmacol., 43(2):168-171.

Sikder K., Sinha M., Das N., Das D. K.R., Datta S. and Dey S. (2013): M. oleifera Leaf Extract Prevents in Vitro Oxidative DNA Damage. Asian J. Pharma. Clin. Res., 6 (2): 159-163.

Singh A., Bhat T.K. and Sharma O.P. (2011a): Clinical Biochemistry of Hepatotoxicity. J.of Cln. Toxico., 9: 4.

Singh S., Singh S.K., Kumar M., Chandra K. and Singh R. (2011b): Ameliorative Potential of Quercetin Against APAP-Induced Oxidative Stress in Mice Blood. Toxicol Int., 18: 140-145.

Stohs S. J. and Hartman M. J. (2015): Review of The Safety and Efficacy of M. oleifera . Phytother. Res., 29: 796-804.

Szasz, G. and Persijn J.P. (1974):Determination of Glutamyl transferase Activity. Clin. Chem. Clin. Biochem., 12:228.

Verma A.R., Vijayakumar M., Mathela C.S. and Rao C.V. (2009): In vitro and in vivo Antioxidant Properties of Different Fractions of M. oleifera Leaves. Food Chem. Toxicol. J., 47(9): 2196 - 2201.

Vongsak B., Sithisam P. and Gritsanapan W. (2014): Simultaneous HPLC Quantitative Analysis of Active Compounds in Leaves of M. oleifera Lam. J. Chromatogr. Sci., 52: 641-645.

Yesmin F., Rahman Z., Dewan J.F., Helali A.M., Islam M.Z., Rahman N.I.A., Muda T., and Haque M.(2013):Hepatoprotective Effect of Aqueous and N-hexane Extract of Nigella Sativa in APAP Induced Liver Diseases of Rats. Inter. Res. J. of Pharma.,4 (7):90-94. 


\title{
الملخص باللغة العربية
}

دراسة مقارنة لكلا من المستخلص المائي والزيتي لأوراق نبات المورينجا على الاستجابة المناعية وحالة الكبد المتأكسد في الجرذان

\author{
فاطمة عبد الحميد خليل, هناء مصطفى عبدالفتاح, هبة عادل عبد الحميد بركات,علياء محمد صلاح \\ قسم الكيمياء الحيوية والتغذية ـ كلية البنات - جامعة عين شمس.
}

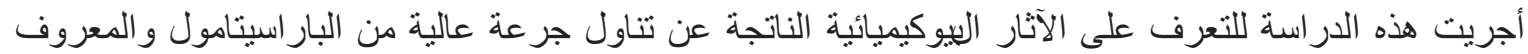

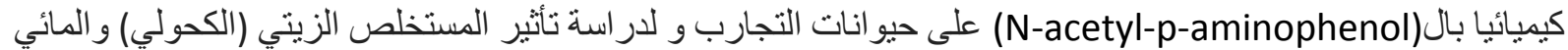

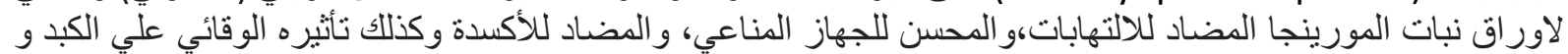

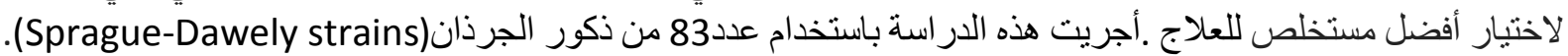

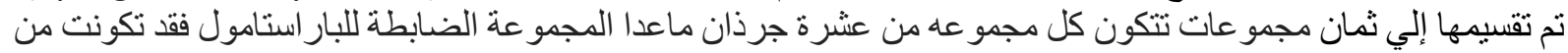

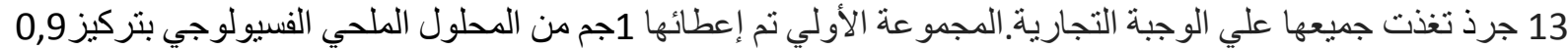

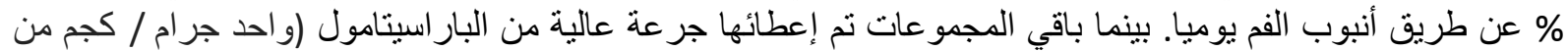

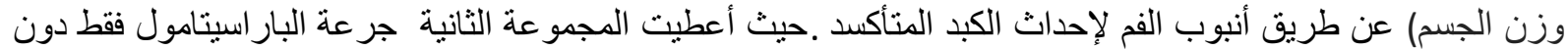

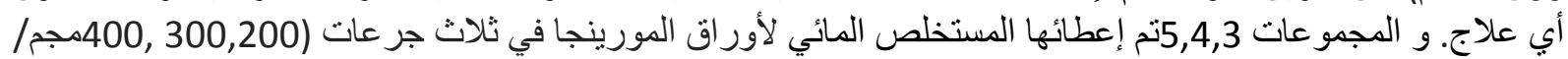

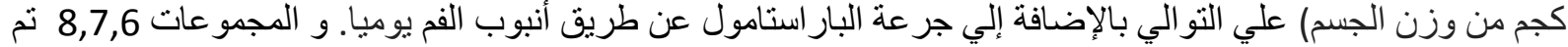

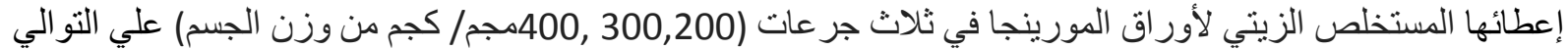

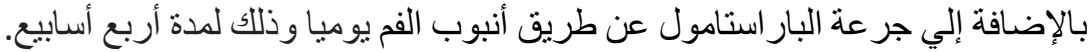

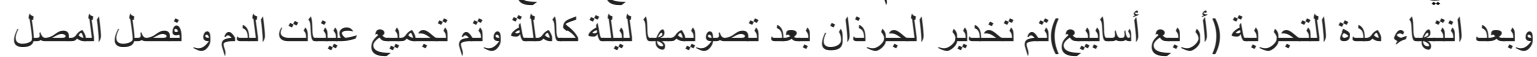

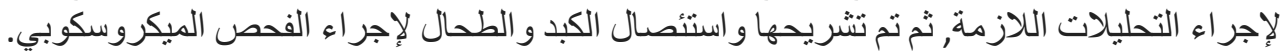

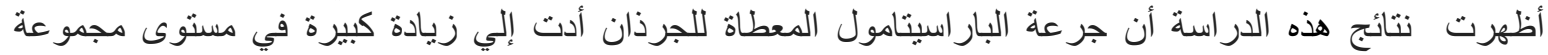

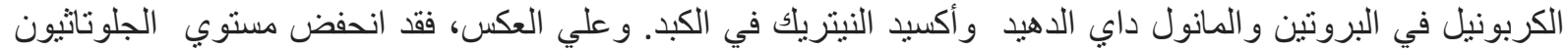

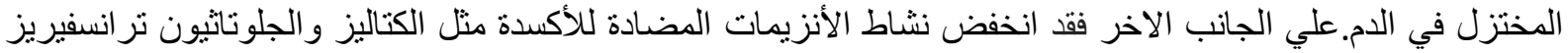

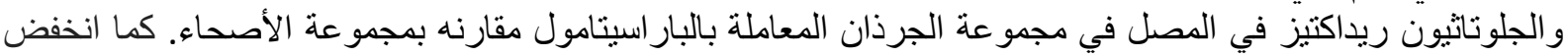

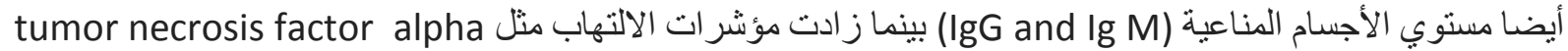

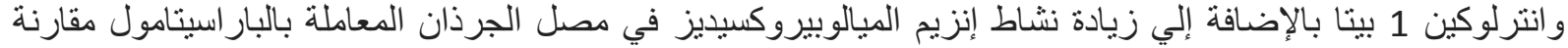

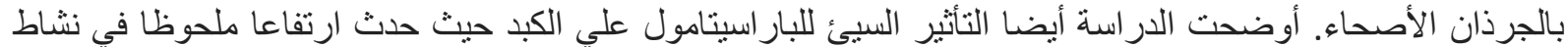

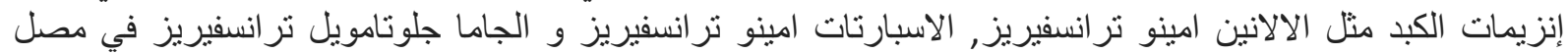

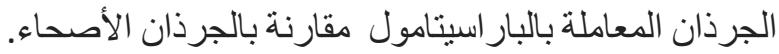

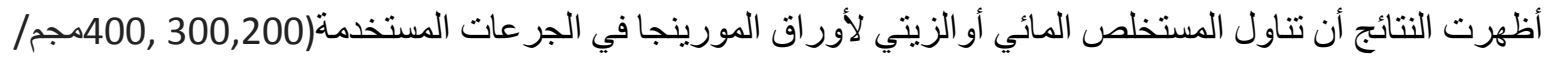

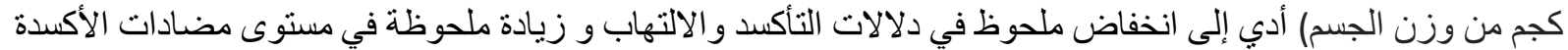

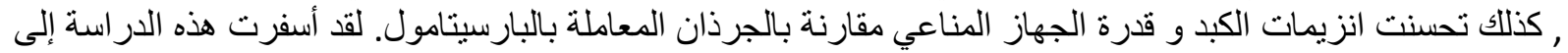

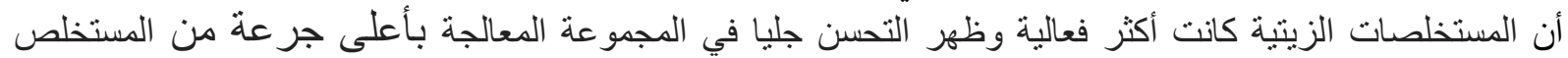

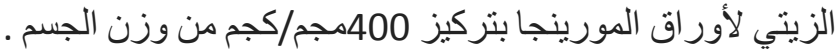

